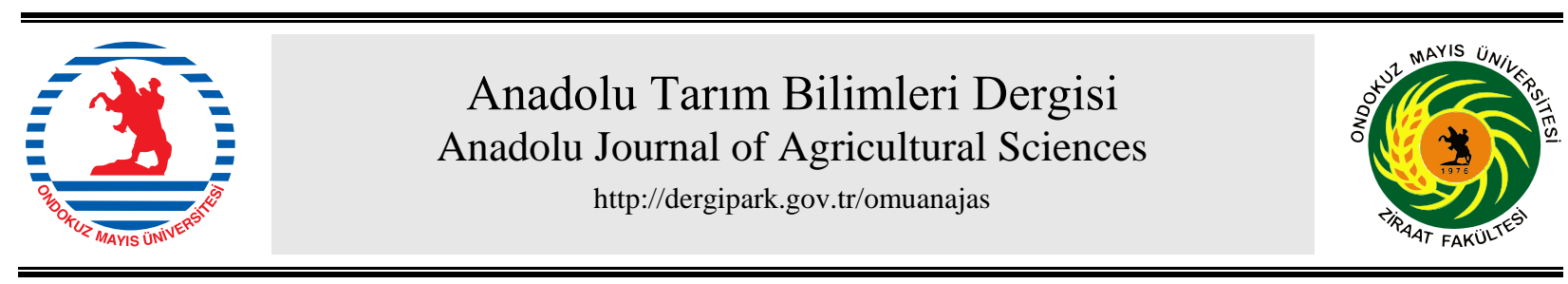

Research/Araştırma

Anadolu Tarım Bilim. Derg./Anadolu J Agr Sci, 33 (2018) ISSN: 1308-8750 (Print) 1308-8769 (Online) doi: 10.7161/omuanajas.407998

\title{
Effects of different growth regulators on regeneration of Turkish upland rice
}

\author{
Yilmaz Kaya ${ }^{\mathrm{a} *}$, Selin Karakütük ${ }^{\mathrm{b}}$ \\ ${ }^{*}$ Department of Agricultural Biotechnology, Faculty of Agriculture, Ondokuz Mayis University, Samsun, Turkey \\ ${ }^{b}$ Department of Agricultural Biotechnology, Graduate School of Sciences, Ondokuz Mayis University, Samsun, Turkey \\ "Corresponding author/Sorumlu yazar: yilmaz.kaya@ omu.edu.tr
}

Geliş/Received 20.03.2018 Kabul/Accepted 01. 08.2018

\begin{abstract}
Rice is a staple crop grown in the world especially in the Asian region. The rice faces with different biotics and abiotic stress factors, especially drought stress. Turkish upland rice is one of the special rice types grown on drought stress condition, having a large potential value. Our aim was to analyse the effects of different concentrations of BAP+NAA and $\mathrm{KIN}+2,4-\mathrm{D}$ combination on rice grown in vitro condition. For this purpose, mature seeds of Turkish upland rice were selected as starting material for direct/indirect regeneration response in serial treatment. The best medium for induction of shoot regeneration was $\mathrm{MS}_{1}$ supplemented with $1.5 \mathrm{mg} \mathrm{L}^{-1} \mathrm{BAP}$ and $0.5 \mathrm{NAA} \mathrm{mg} \mathrm{L}{ }^{-1}$. The results showed that the maximum callus formation $(65.54 \%)$ was obtained on MS medium containing 2.4-D (2.0 $\mathrm{mg} \mathrm{L}^{-}$ 1) within 21 days from nodes. With this study, we have developed a plant tissue culture for Turkish upland rice, suggesting positive methods for rice biotechnology.
\end{abstract}

Farklı büyüme düzenleyicilerin Türk kır çeltiği rejenerasyonuna etkisi

ÖZET

Çeltik bitkisi, tüm Dünya'da ve özellikle Asya kıtasında yetişen temel bir üründür. Çeltik, kuraklık stresi gibi farklı abiyotik ve biyotik stres faktörleri ile karşı karşıyadır. Türk kır çeltiği, kuraklık stres koşullarında yetişen ve büyük bir potansiyele sahip olan üstün çeltik türlerinden biridir. Bu çalışmanın amacı, BAP + NAA ve KIN + 2.4-D kombinasyonunun farklı konsantrasyonlardaki in vitro koşullarda yetiştirilen çeltik üzerindeki etkilerini incelemektir. Bu amaçla, başlangıç materyali olarak olgun çeltik tohumları kullanılmış olup direkt ve indirekt rejenerasyon sonuçları kaydedilmiştir. Gövde rejenerasyonu indüksiyonu için en iyi ortam, $1.5 \mathrm{mg} \mathrm{L}^{-1} \mathrm{BAP}$ ve $0.5 \mathrm{NAA} \mathrm{mg} \mathrm{L}^{-1}$ ile desteklenmiş $\mathrm{MS}_{1}$ olmuştur. Sonuç olarak, gövde nodların 21 gün içinde 2.4-D (2.0 $\left.\mathrm{mg} \mathrm{L}^{-1}\right)$ içeren MS ortamı üzerinde maksimum kallus oluşumunun (\% 65.54) elde edildiğini kaydedilmiştir. Bu çalışma ile Türk kır çeltiği için doku kültürü optimizasyonu geliştirirmiştir ve çeltik biyoteknolojisi açısından pozitif metotlar sunulmuştur.

Keywords:

Callus

Plant Regeneration

BAP

NAA

KIN

2.4-D

\section{Introduction}

Cultivated rice is world' single most important grain (Horuz, 2014). Rice is stable food for more than half of the Asian consumption. Upland rice, a dry farming ecotype of cultivated rice, is commonly directly seeded without a water layer cover. Additionally, upland rice is one of special rice types grown on limited irrigation conditions (Din et al., 2016; Kaya et al., 2017). The rice is proper for low-lying, hilly countryside, rainy mountainous areas and waterlogged upland regions, and rice paddy fields with limited water irrigation (Jahan et al., 2017).

Furthermore, the upland rice is more drought resistant than lowland rice. In addition, Jahan et al., (2015) have been highlighted to identify the genetic and biochemical mechanisms helping rice to overcome with toxicities of toxic substance like iron ions. Thus, given a global shortage of water resources, the drought resistant properties of upland rice make it ideal for sustainable rice production and food security. Abiotic stress such as drought stress is an important issue for rice production around the world due to lower productivity as compared with flooded rice. Furthermore, $12 \%$ of global paddy production is upland rice. The increases in world rice production over the past years has been resulted from successes in research and the transfer of biotechnology. However, these successes had virtually much effect on 
upland rice production in the world (Karakütük, 2017). Also, recently years, new upland rice cultivars have been developed on around the world (Din et al., 2016). Some of the cultivars show high drought tolerance (Yang et al., 2004) and high yield potential (Bouman et al., 2006).

Upland rice improvement, the applications of biotechnological methods are limited by the availability of in vitro plant regeneration approaches (Din et al., 2016). On the other hand, plant tissue culture is one the most important steps of plant regeneration and gene transfer among modern methods (Kaya et al., 2013). In addition, several strategies need to be devised to improve upland rice productivity via the conventional breeding methods along with recent achievement in biotechnological breeding to balance the world consumption of rice (Shahsavari, 2010; Shahsavari et al., 2010). For the reason, upland rice genetic transformation needs to be applied to address abiotic factors such as drought stress, hindering the upland rice production. The upland rice genetic transformation systems require an essential step of in vitro plant regeneration from explant of upland rice.

Until now, several reports have been shown in vitro regeneration of upland rice especially Malaysian upland rice(Din et al., 2016; Zhao et al., 2011; Shahsavari, 2011; Shahsavari et al., 2010; Shahsavari, 2010; Geng et al., 2008). To the best of our knowledge, no reports are available in literature for tissue culture of Turkish upland rice. Therefore, the purpose of this research constitutes the first ever successful and complete in vitro propagation of protocol for Turkish upland rice.

\section{Materials and Methods}

\subsection{Source of explants}

Fresh and healthy mature seeds were collected from Eastern Anatolia region of Turkey in 2015. Turkish upland rice local namely Kır Çeltiği were used for this research. Seeds were stored in plastic bags at $4^{\circ} \mathrm{C}$ as the source of explant for all experiments.

\subsection{Surface sterilization}

Mature seeds of Turkish upland rice were dehusked and rinsed thrice using sterile double distilled water. The seed were then sterilised by immersed in $60 \%$ ethanol for 55 seconds, then washed 2 times with double distilled water, followed by $50 \%$ Clorox for 18 minutes. Treated seeds were washed again with double distilled water for five times. Treated seeds were blotted dry on sterile tissue paper. The sterile seeds were placed on MS media and kept at $25 \pm 2{ }^{\circ} \mathrm{C}$.

\subsection{Indirect and direct regeneration from explants}

Sterilized seeds were cultured on a basal MS (Murashige and Skoog, 1962) medium, including $30 \mathrm{~g}$
$\mathrm{L}^{-1}$ sucrose and $0.3 \%$ phytagel was designed as $\mathrm{MS}_{1}$. For subculture, all medium were transferred into fresh same media in same condition after 15 days. Plant regeneration from seed grown well. After 25 days, we used the plants for source of explants. For direct regeneration, nodes and leaves were cultures on medium consisting $\mathrm{MS}_{1}$, BAP $\left(0.5,1,1.5,2.0 \mathrm{mg} \mathrm{L}^{-1}\right)$ alone and in combination with NAA $\left(0.5,1.0 \mathrm{mg} \mathrm{L}^{-1}\right)$. Also explants were places on $\mathrm{MS}_{1}$ supplemented with 2.4-D alone $\left(0.5,1,1.5,2.0 \mathrm{mg} \mathrm{L}^{-1}\right)$ and in combination with KIN $\left(0.5,1.0 \mathrm{mg} \mathrm{L}^{-1}\right)$. Each treatment contained 12 seeds with 3 replicates and even the experiments were repeated 3 times. The sterilized seeds were incubated under $16 / 8 \mathrm{~h}$ (light/dark) photoperiod at $25 \pm 2{ }^{\circ} \mathrm{C}$ for 25 days.

\subsection{Statistical analysis}

The experiments were arranged in a completely randomized design with three replications. All reactions were performed with three technical and three biological replicates. One-way analysis of variance was used on experimental data in addition to post hoc Tukey's test has via IBM SPSS for windows v.20.

\section{Results and Discussion}

This is the first complete protocol for in vitro tissue culture optimization of Turkish upland rice. In vitro seeds germination and seedling development of Turkish pland rice were successfully performed (Fig. 1). Multiple shoot and root were achieved explant of Turkish upland rice onto the $\mathrm{MS}_{1}$ medium. After incubation on the MS media, seeds became swollen quickly and germination occurred within the first 5 days of culture (Fig. 1. A-C) and the growth of regeneration was started followed root (Fig. 1. D). After 15 days, (Fig. 1. E) the samples were subcultured (Fig. 1. F).

Leaves and nodes from aseptically grown plants of Turkish upland rice (Fig. 1. G) were used as explants. The leaves (Fig. 1. H) and the nodes (Fig. 1. I) were excised from 25 days-old seedlings, and were cultured on MS medium containing various concentration of $\mathrm{BAP}+\mathrm{NAA}$ and $\mathrm{KIN}+2,4-\mathrm{D}$. In vitro tissue culture continued over a period of four weeks to the increase stock. Node explants with leaf primordia appeared seven days after culture initiation from node explants (F1. J). Adventitious shoot or multiple shoots (Fig. 1. J) formation was achieved directly from the cut edges of the node explants. There was no regeneration from leaf explant (data not shown) (Fig. 1. J-K).

The mean shoot number per explant varied between $8.90 \pm 1.55$ and $30.34 \pm 0.59$, and the highest shoot formation was $91.17 \%$ on MS medium containing 1.5 mg L ${ }^{-1}$ BAP $+0.5 \mathrm{mg} \mathrm{L}^{-1}$ NAA (Table 1). Also, the lowest frequency of shoot formation from node explants was $41.46 \%$ recorded MS medium supplemented with $0.5 \mathrm{mg} \mathrm{L}^{-1}$ BAP alone (Table 1). 


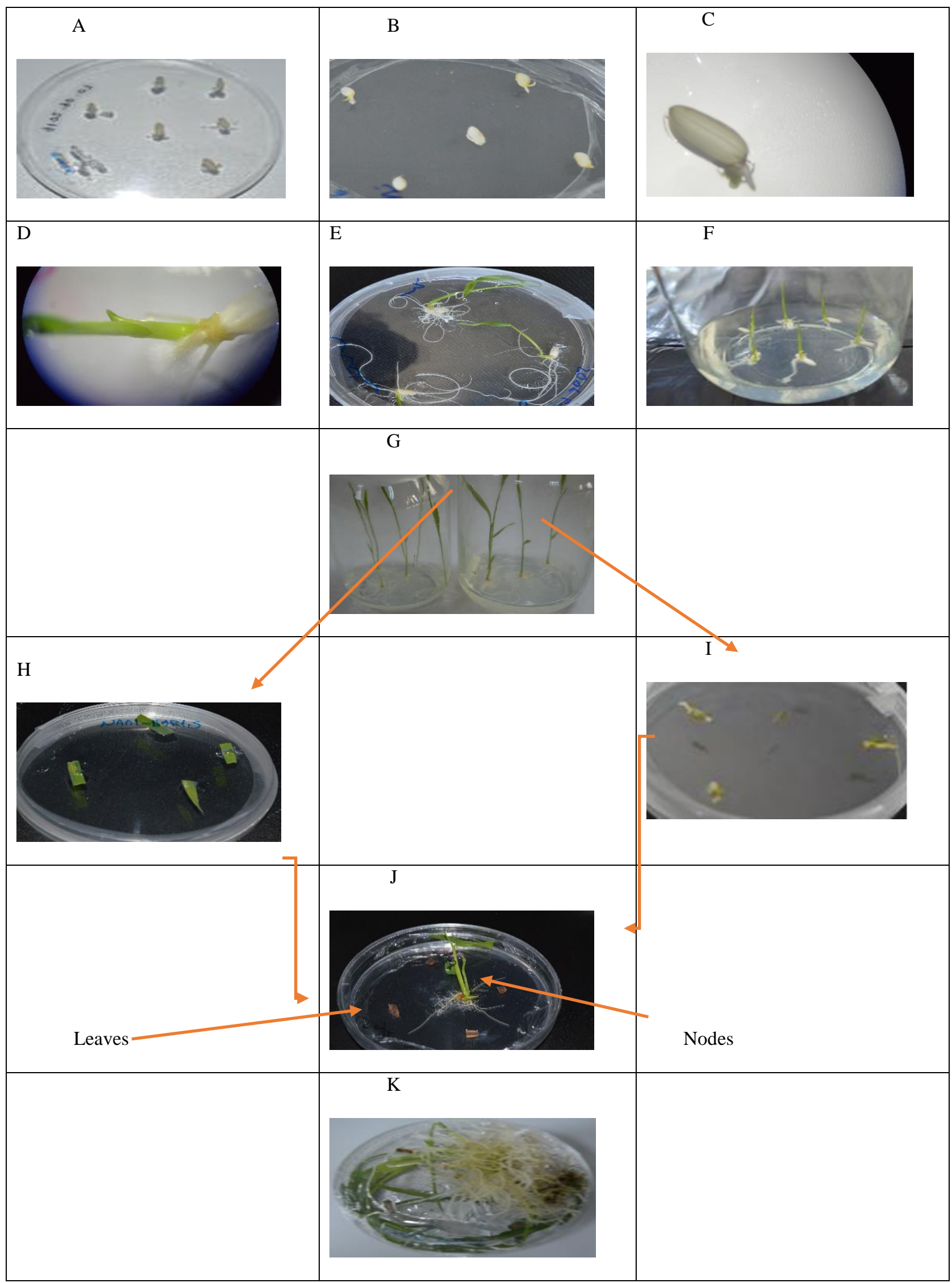

Figure 1. Direct plant regeneration from seed on $\mathrm{MS}_{1}$ medium 
Among different concentrations of 2,4-D and KIN tested, $\mathrm{MS}_{1}$ media containing $0.5 \mathrm{mg} \mathrm{L}^{-1} 2,4-\mathrm{D}$ and $1.0 \mathrm{mg} \mathrm{L}^{-1} \mathrm{KIN}$ produced the highest shoot formation $(75.82 \%)$ with healthy regeneration. The lowest shoot formation $(43.37 \%)$ was achieved on the $\mathrm{MS}_{1}$ consisting of $2.0 \mathrm{mg} \mathrm{L}^{-1} 2.4-\mathrm{D}$ alone (Table 2). The mean shoot number per explant varied between
$08.21 \pm 0.97$ and $18.70 \pm 1.18$. The highest regeneration number was $18.70 \pm 1.18$ on MS medium containing 1.0 2.4-D $\left(\mathrm{mg} \mathrm{L}^{-1}\right)+1.0 \mathrm{KIN}\left(\mathrm{mg} \mathrm{L}^{-1}\right)$ (Table 2). Also, the mean highest callus induction was $65.54 \%$ in MS medium supplemented with, $2.0 \mathrm{mg} \mathrm{L}^{-1}$ 2,4-D alone (Table 2).

Table 1. The effects of different BAP and NAA hormone concentrations on node explant

\begin{tabular}{lcccc}
\hline MS & \multicolumn{2}{c}{ Plant Growth Regulators } & $\begin{array}{c}\text { The shoot } \\
\text { formation }(\%)\end{array}$ & $\begin{array}{c}\text { The mean shoot number } \\
\text { per explant }\end{array}$ \\
\cline { 2 - 3 } 1 & BAP $\left(\mathrm{mg} \mathrm{L}^{-1}\right)$ & NAA $\left(\mathrm{mg} \mathrm{L}^{-1}\right)$ & $41.46^{\mathrm{b}}$ & $12.10 \pm 1.30^{\mathrm{b}}$ \\
2 & 0.5 & - & $50.44^{\mathrm{k}}$ & $09.89 \pm 1.95^{\mathrm{f}}$ \\
3 & 1.0 & - & $64.66^{\mathrm{h}}$ & $15.33 \pm 0.88^{\mathrm{e}}$ \\
4 & 1.5 & - & $73.07^{\mathrm{f}}$ & $19.02 \pm 0.77^{\mathrm{d}}$ \\
5 & 2.0 & - & $61.55^{\mathrm{i}}$ & $06.20 \pm 0.90^{\mathrm{g}}$ \\
6 & 0.5 & 0.5 & $81.36^{\mathrm{c}}$ & $21.51 \pm 1.52^{\mathrm{b}}$ \\
7 & 1.0 & 0.5 & $91.17^{\mathrm{a}}$ & $30.34 \pm 0.59^{\mathrm{a}}$ \\
8 & 1.5 & 0.5 & $85.22^{\mathrm{b}}$ & $25.13 \pm 2.02^{\mathrm{b}}$ \\
9 & 2.0 & 0.5 & $67.84^{\mathrm{g}}$ & $18.63 \pm 1.10^{\mathrm{d}}$ \\
10 & 0.5 & 1.0 & $78.42^{\mathrm{d}}$ & $21.80 \pm 1.80^{\mathrm{c}}$ \\
11 & 1.0 & 1.0 & $75.66^{\mathrm{c}}$ & $20.09 \pm 2.39^{\mathrm{d}}$ \\
12 & 1.5 & 1.0 & $57.63^{\mathrm{j}}$ & $08.90 \pm 1.55^{\mathrm{f}}$ \\
\hline
\end{tabular}

Table 2. The effects of different 2,4-D and KIN hormone concentrations on node explant

\begin{tabular}{|c|c|c|c|c|c|}
\hline \multirow{2}{*}{$\begin{array}{l}\text { MS } \\
\text { Medium }\end{array}$} & \multicolumn{2}{|c|}{ Plant Growth Regulators } & \multirow{2}{*}{$\begin{array}{l}\text { The mean callus } \\
\text { formation }(\%)\end{array}$} & \multirow{2}{*}{$\begin{array}{c}\text { The shoot } \\
\text { formation (\%) }\end{array}$} & \multirow{2}{*}{$\begin{array}{c}\text { The mean shoot } \\
\text { number per explant }\end{array}$} \\
\hline & $2,4-\mathrm{D}\left(\mathrm{mg} \mathrm{L}^{-1}\right)$ & $\mathrm{KIN}\left(\mathrm{mg} \mathrm{L} \mathrm{L}^{-1}\right)$ & & & \\
\hline 1 & 0.5 & - & $37.95^{\mathrm{d}}$ & $69.15^{\mathrm{b}}$ & $15.12 \pm 1.71^{\mathrm{d}}$ \\
\hline 2 & 1.0 & - & $45.52^{\mathrm{c}}$ & $69.20^{\mathrm{d}}$ & $13.13 \pm 1.19^{\mathrm{c}}$ \\
\hline 3 & 1.5 & - & $53.46^{\mathrm{b}}$ & $50.46^{\mathrm{j}}$ & $15.33 \pm 0.88^{\mathrm{e}}$ \\
\hline 4 & 2.0 & - & $65.54^{\mathrm{a}}$ & $43.37^{\mathrm{k}}$ & $08.21 \pm 0.97^{\mathrm{j}}$ \\
\hline 5 & 0.5 & 0.5 & $7.20^{\mathrm{j}}$ & $65.04^{\mathrm{f}}$ & $10.90 \pm 0.90^{\mathrm{f}}$ \\
\hline 6 & 1.0 & 0.5 & $10 . .22^{\mathrm{i}}$ & $58.90^{\mathrm{g}}$ & $10.01 \pm 1.72^{\mathrm{g}}$ \\
\hline 7 & 1.5 & 0.5 & $33.43^{\mathrm{e}}$ & $56.34^{\mathrm{i}}$ & $09.34 \pm 0.90^{\mathrm{h}}$ \\
\hline 8 & 2.0 & 0.5 & $24.43^{\mathrm{g}}$ & $58.39^{\mathrm{h}}$ & $10.90 \pm 2.01^{\mathrm{g}}$ \\
\hline 9 & 0.5 & 1.0 & $26.72^{1}$ & $75.82^{\mathrm{a}}$ & $17.63 \pm 2.11^{\mathrm{b}}$ \\
\hline 10 & 1.0 & 1.0 & $20.38^{\mathrm{h}}$ & $71.80^{\mathrm{b}}$ & $18.70 \pm 1.18^{\mathrm{a}}$ \\
\hline 11 & 1.5 & 1.0 & $35.38^{d}$ & $70.93^{b}$ & $16.19 \pm 1.36^{\mathrm{d}}$ \\
\hline 12 & 2.0 & 1.0 & $3.88^{\mathrm{k}}$ & $66.39^{c}$ & $14.44 \pm 1.15^{\mathrm{c}}$ \\
\hline
\end{tabular}

In this research, the tissue culture optimization of Turkish upland rice was evaluated. The finding obtained from research have emphasised the best concentration and composition of plant growth regulators (PGRs) (2,4-D, BAP, KIN and NAA). Variety concentration of 2,4-D growth regulator is one of the most effective ways for acquiring callus formation (Karthikeyan et al., 2009). In addition, BAP, NAA, NAA and KIN growth regulator combinations are one of the most effective combinations for regeneration of plants (Ali et al., 2004; Kurt et al., 2008; Shahsavari, 2010; Sahoo et al.,2011; Din et al., 2016;). Until now, there are several reports in
Malaysian upland rice and Chinese upland rice such as those reported by Ali et al., 2004; Shahsavari, 2010; Din et al., 2016). However, there is no study on tissue culture optimization of Turkish upland rice.

Further, the use of 2.4-D was observed as for micropropagation through calluses for our research. However, our finding proved that the 2.4-D growth regulator $2 \mathrm{mg} \mathrm{L}^{-1}$ alone induced better callus induction frequency $(65.54 \%)$. Our finding was also in contrast to previous findings on other upland rice such as Malaysian upland rice on grown $\mathrm{MSB}_{5}$ and MS medium consist of 2.4-D only (Shahvari, 2010; Din et al., 2016). 
Nevertheless, our results were agreements with Sah et el., (2014) who observed that 2.4-D growth regulator with variety of concentration gave better response to callus formation in Oryza sativa indica. Also, our observations suggested that high concentration of 2.4-D (2.0 $\mathrm{m} \mathrm{L} \mathrm{L}^{-1}$ ) caused the callus become brown and low quality for in vitro plant regeneration (Data not shown). Ali et al. (2004) and Rueb et al. (1994) suggested high does concentration of 2.4-D could induce a negative effect on callusing. Similar reduction in quantity of 2.4D was reported Malaysian upland rice (Din et al., 2016). As a result of our research, we suggested that less than 2 $\mathrm{mg} \mathrm{\textrm {L } ^ { - 1 }}$ 2.4-D alone resulted in the highest callus formation.

Direct plant regeneration from seeds was observed within 7 days culture Seed germination often preceded regeneration on MS media containing the variety concentration of BAP. Also, the average of plant direct regeneration from seed on MS medium added with BAP $\left(0.5,1,1.5,2 \mathrm{mg} \mathrm{L}^{-1}\right)$ were statistically different from each other. In contrast, Wang et al., (2011) have studied hybrid of indica rice species for tissue culture system, and the growth regulator concentrations (BAP, NAA) were attempted for in vitro plant regeneration from seed. We applied the same growth regulators, but their results were not similar to ours. Therefore, the results of that study were in contrast with our findings. Because our genotypes and type of rice are different from that study.

In the current research, Turkish upland rice was used for tissue culture optimization through explants from leaves and nodes. Nodes explant in monocot plants is an excellent source of analysing the ability of tissue culture responsive to initiate regeneration plants for rice (Ramesh et al., 2009; Kurt, 2015, Kurt, 2016, Karakütük, 2017).

The effect of BAP+NAA was studied and recorded that the growth regulator concentration enhanced the regeneration of plant from explant for nodes (Kurt, 2016). Similarly, in some Turkish varieties of rice, multiple plant regeneration was achieved in added of MS medium supplemented BAP+NAA. Simultaneously, positive effect of NAA in combination with BAP has been previously reported to facilitate plant regeneration in rice (Kurt, 2008; Shekar et al., 2016; Kurt, 2016). The observed results revealed that KIN was an effective operation in plant regeneration of rice culture (Shekar, 2016; Kurt, 2016). However, our research recorded that the combination 2.4-D and KIN negative effected for plant regeneration from explant of nodes. Based on our findings, we suggested that a combination of BAP and NAA produced higher percentage of Turkish upland rice regeneration from explant of nodes. Also, our results indicated that a combination of 2,4-D and KIN produced less percentage of Turkish upland rice regeneration from explant of nodes. Since the same growth regulator composition is not suitable for all rice variety, the modifying media were diversified to overcome the genotypic influence for particular rice varieties either upland rice or wetland rice.

\section{Conclusion}

The current research showed establishment on callus induction using 2.4-D for Turkish upland rice from seed. Also, our results indicated that plant regeneration from seed using BAP, NAA, 2.4-D and KIN for Turkish Upland rice. Also, it was recorded that best concentrations of growth regulators alone and in combinations (NAA+BAP and 2.4-D+KIN) has significantly enhanced the regeneration of Turkish upland rice from explant of nodes.

In conclusion, an efficient technique for in vitro germination of seeds and regeneration of callus induction of seed from seed and explant for Turkish upland rice has been described. This is the first report about in vitro propagation of Turkish upland rice. Our findings could be useful for tissue culture optimization of Turkish upland rice.

\section{Acknowledgments}

The authors would like to thank Ondokuz Mayis University for financial support of the project (PYO.ZRT.1911.15.001).

\section{References}

Ali, S., Xue, Q., Zhang, X., 2004. Assessment of various factors involved in the tissue culture system in rice. Rice Sci. 11:345-349.

Bouman, B.A.M., Yang, X., Wang, H., Wang, Z., Zhao, J., Chen, B., 2006. Performance of aerobic rice cultivars under irrigated conditions in North China. Field Crops Research. $\quad 9, \quad 53-65$. https://doi.org/10.1016/j.fcr.2005.08.015

Din Mohd, A.R.J., Iliyas, A.F., Wagiran, A., Abd Samad, A., Rahmat, Z., Sarmidi, M.R., 2016. Improvement of efficient in vitro regeneration potential of mature callus induced from Malaysian upland rice seed (Oryza sativa cv. Panderas). Saudi Journal of Biological Sciences. 23(1), pp. 69-77. http://doi.org/10.1016/j.sjbs.2015.10.022

Geng, P.P., La, H.G., Wang, H.Q., Stevens E.J.C., 2008. Effect of sorbitol concentration on regeneration of embryogenic callus in upland rice varieties (Oryza sativa L.). Plant Cell Tissue Organ Cult., 92:, 303-313. https://doi.org/10.1007/s11240-007-9321-5

Horuz, A., Korkmaz, A., 2014. Çeltikte (Oryza sativa L.) Tuz stresinin azaltılmasında silisyumlu gübrelemenin etkisi. Tarım Bilimleri Dergisi, 20: 215-229.

Jahan, N., Norshila, F., Javed, M.A., Samiullah, K., Siti, Z., 2015. Effects of ferrous toxicity on seedling traits and Ion Distribution pattern in Upland and Low Land Rice under hydroponic conditions. Jurnal Teknologi, eISSN 21803722 |DOI: 10.11113/jt.v78.7258.

Jahan, N., Javed, M.A., Manan, F.A., Khan, S., Samad A.A., Zaidi, M.I.0., 2017. Comparative study of physiological and growth parameters for sodium and iron toxicities in upland and lowland cultivars of Oryza sativa L. Pak. J. Bot., 49(SI): 249-254. 
Karakütük, S., 2017. Türkiye'de yetiştirilen kır çeltik çeşitlerinin in vitro koşullarda doku kültürü parametrelerinin ve kurakliğa toleranslarinin belirlenmesi. Yüksek Lisans Tezi. Ondokuz Mayis Üniversitesi. Samsun. S. 50-55.

Karthikeyan A., Pandian S.T.K, Ramesh, M., 2009. High frequency plant regeneration from embryogenic callus of a popular indica rice (Oryza sativa L.). Phys. Mol. Biol. Plants, 15: 371-375. https://doi.org/10.1007/s12298-0090042-6.

Kaya, Y., Marakli, S., Gozikirmizi, N., Mohamed, E., Javed, MA., Huyop, F., 2013. Herbicide tolerance genes derived from bacteria. The J. Anim. Plant Sci., 23(1): 85-91.

Kaya, Y., Kuyumcu, G., Karakütük, S., Arvas Y.E., 2017. Kır çeltik bitkisi. Yüzüncü Y1l Üniversitesi Tarım Bilimleri Dergisi, 27 (1):151-156. doi: 10.29133/yyutbd.305114

Kurt, O., Aydın, E., Seyis, F., 2008. Farklı somatik explantların çeltikte (Oryza sativa L. cv. Taipei-309) kallus ve bitkicik oluşumuna etkisi. Biyoloji Bilimler Araştırma Dergisi, 1(1):1-3.

Kurt, O., 2015. Hücre ve doku kültürü. Bitki 1slahı ders kitab1, No: 43 (5. Basım). Ondokuz Mayıs Üniversitesi, Ziraat Fakültesi. Samsun.

Kurt, S., 2016. Çeltik (Oryza sativa L.)'te somatik dokulardan kallus oluşumu ve bitki elde etme Olanakları,. Yüksek Lisans Tezi. Ondokuz Mayıs Üniversitesi, Samsun. S.6063.

Murashige, T., Skoog, F., 1962. A revised medium for rapid growth and bioassays with tobacco tissue cultures, Physiologia Plantarum, 15 (3): 473-497

Ramesh, M., Murugiah, V., Gupta AK., 2009. Efficient in vitro plant regeneration via leaf base segments of indica rice, Ind. J. Exp. Biol., 47: 68-74

Rueb, S., Leneman, M., Schilperoor, R., Hensgens, A., 1994. Efficient plant regeneration through somatic embryogenesis from callus induced on mature rice embryos (Oryza sativa L.). Plant Cell Tissue and Organ Culture, 36:

259-264.
Sah, S. K., Kaur, A., Singh, J., (2014). High Frequency Embryogenic Callus Induction and Whole Plant Regeneration in Japonica Rice Cv. Kitaake. J Rice Res 2:125. doi: 10.4172/jrr.1000125

Sahoo, K.K., Tripathi, A.K., Pareek, A., Sopory, S.K., SinglaPareek, S.L., 2011. An improved protocol for efficient transformation and regeneration of diverse indica rice cultivars. Plant Methods, 7: 49-59. DOI: 10.1186/17464811-7-49

Shahsavari, E., 2010. Evaluation and optimizations of media on the tissue culture system of upland rice. Int. J. Agric. Biol., 12: 537-540. Doi.org/10-177/MMI/2010/12-4537-540.

Shahsavari, E., 2011. Impact of tryptophan and glutamine on tissue culture of upland rice. Plant Soil Environ., 57: 710 .

Shahsavari, E., Maheran, AA., Siti, Nor, Akmar, A., Hanafi, MM., 2010. The effect of plant growth regulators on optimization of tissue culture system in Malaysian upland rice. Afr. J. Biotechnol, 9: 2089-2094. DOI: 10.5897/AJB10.1925.

Shekar, S.R.S., Singh, B., 2016. Optimization of regeneration using differential growth regulators in indica rice cultivars. 3 Biotech. 6(19). pp. 2-7. ISSN: 2190-572X (Print) 2190-5738 (Online).

Yang, C., Yang, L., Yang, Y., Ouyang, Z., 2004. Rice root growth and nutrient uptake as influenced by organic manure in continuously and alternately flooded paddy soils. Agricultural Water Management, 70: 67-81.

Zhao, W., Zheng, S., Ling, H., 2011. An regeneration system and Agrobacterium-mediated transformation of Chinese upland rice cultivar Handao297. Plant Cell Tissue Organ Cult., 106: 475-483.

Wang, LG., Lin, DZ., Wang, JC., 2011. Tissue culture system for different hybrid of Indica Rice. Journal of Northeast Agricultural University, 18(2): https://doi.org/10.1016/S1006-8104(12)60003-8 https://doi.org/10.1007/BF00037729 